\title{
Bimbingan Teknis Pencatatan Transaksi Keuangan Dalam Meningkatkan Daya Saing UKM Kabupaten Bojonegoro di Era Industri 4.0
}

\author{
Nenny Syahrenny ${ }^{1 *}$, Emi Kusmaeni², Iffah Qonitah ${ }^{3}$ \\ 1,2,3 Sekolah Tinggi Ilmu Ekonomi Indonesia (STIESIA) Surabaya

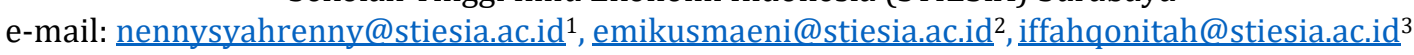 \\ *Penulis Korespondensi: E-mail: nennysyahrenny@stiesia.ac.id
}

\begin{abstract}
Micro, Small and Medium Enterprises in the industrial era 4.0 are still a solution for Indonesians to seek income. Even though they are suffering from increasing competition in business, Micro, Small and Medium Enterprises can still survive because of the tenacity and persistence of business owners. Bojonegoro, one of the districts in East Java Province, also has a large number of Micro, Small and Medium Enterprises. However, these Micro, Small and Medium Enterprises actors still have problems in general, namely not separating personal assets from their businesses, not knowing business developments because the information obtained only comes from sales turnover only. They do not record financial transactions and prepare financial reports on the grounds that they do not have knowledge of accounting and how to prepare these financial statements. Therefore, we provide a solution by holding Technical Guidance activities regarding recording financial transactions up to the preparation of Financial Statements in accordance with Financial Accounting Standards for Micro, Small and Medium Entities for Small and Medium Enterprises in Bojonegoro Regency. This activity went on smoothly and the participants became familiar with the recording of financial transactions and how to prepare financial reports in accordance with the Standards. This can be seen from the presence of participants who succeeded in answering the cases given by the resource persons. Participants who answered the questions correctly were given a book on Financial Accounting Standards for Micro, Small and Medium Entities.
\end{abstract}

Keywords: Micro, Small and Medium Enterprises, Financial Accounting Standard for Micro, Small and Medium Entities, record financial transactions, Financial Statement

\begin{abstract}
Abstrak
Usaha Mikro Kecil dan Menengah di era industri 4.0 ini masih menjadi solusi bagi masyarakat Indonesia untuk mencari penghasilan. Meskipun didera persaingan yang semakin tinggi dalam usaha, Usaha Mikro Kecil dan Menengah masih dapat bertahan karena keuletan dan kegigihan dari pemilik usaha. Bojonegoro, salah satu Kabupaten di Provinsi Jawa Timur, juga memiliki Usaha Mikro Kecil dan Menengah dengan jumlah yang tidak sedikit. Namun pelaku Usaha Mikro Kecil dan Menengah ini masih memiliki kendala pada umumnya, yaitu tidak memisahkan aset pribadi dengan usahanya, tidak mengetahui perkembangan usaha dikarenakan informasi yang didapat hanya berasal dari omzet penjualan saja. Mereka tidak mencatat transaksi keuangan dan menyusun Laporan Keuangan dengan alasan tidak memiliki pengetahuan mengenai Akuntansi dan bagaimana cara menyusun Laporan Keuangan tersebut. Oleh karena itu kami memberikan solusi dengan mengadakan kegiatan Bimbingan Teknis mengenai pencatatan transaksi keuangan sampai dengan penyusunan Laporan Keuangan sesuai dengan Standar Akuntansi Keuangan Entitas Mikro, Kecil dan Menengah kepada pelaku Usaha Kecil dan Menengah di Kabupaten Bojonegoro. Kegiatan ini berlangsung lancar dan peserta menjadi paham mengenai pencatatan transaksi keuangan dan bagaimana menyusun laporan keuangan sesuai dengan Standar. Hal ini dapat diketahui dari adanya peserta yang berhasil menjawab kasus yang diberikan oleh narasumber. Peserta yang menjawab pertanyaan dengan benar diberikan buku Standar Akuntansi Keuangan Entitas Mikro, Kecil dan Menengah.
\end{abstract}

Kata kunci: Usaha Mikro Kecil dan Menengah, Standar Akuntansi Keuangan Entitas Mikro Kecil dan Menengahi, pencatatan transaksi keuangan, Laporan Keuangan 


\section{PENDAHULUAN}

Usaha Mikro, Kecil dan Menengah masih menjawab permasalahan ekonomi di Indonesia kapanpun juga. Masyarakat Indonesia mempunyai ketekunan, keuletan, keterampilan dan inovasi yang kreatif dalam menjawab tantangan ekonomi di setiap krisis. Tahun 1998 dimana krisis moneter melanda Indonesia, banyak masyarakat tidak mempunyai pekerjaan karena di-PHK (Pemutusan Hubungan Kerja) oleh perusahaan tempatnya bekerja. Para pekerja yang terkena dampak krisis moneter tersebut akhirnya memutuskan membuka usaha sendiri dengan berbekal keterampilan yang diperoleh ketika masih bekerja, sehingga saat itu mulai banyak bermunculan para pelaku UMKM (Usaha Mikro, Kecil dan Menengah).

Sampai di tahun era industri 4.0 sekarang dimana semua perusahaan berusaha merubah strategi bisnis dan mengimplementasikan penggunaan teknologi, UMKM (Usaha Mikro, Kecil dan Menengah) masih bisa bertahan di tengah derasnya persaingan. Perkembangan UMKM pun juga semakin pesat dari tahun ke tahun. Menurut data dari Dinas Koperasi dan UKM Provinsi Jawa Timur terdapat ada sekitar 3 jutaan UKM yang terdaftar di Jawa Timur saja.

Menjamurnya UMKM di Indonesia mendapat perhatian dari Pemerintah Negara ini. Berbagai program bantuan banyak diberikan kepada pelaku UMKM untuk meningkatkan daya saing. Pemerintah Indonesia di tahun 2016 mengeluarkan Peraturan Pemerintah mengenai Strategi Nasional Keuangan Inklusif dimana didalam strategi tersebut salah satu tujuannya adalah memberikan program pelatihan kepada UMKM.

Potensi UMKM cukup besar dalam menyumbang pendapatan domestik bruto, namun kelemahan dari UMKM masih juga belum teratasi dari tahun ke tahun sehingga banyak diantaranya yang pada akhirnya tidak lama dalam membuka usahanya. Kelemahan UMKM secara umumnya adalah rendahnya pendidikan, kurangnya pemahaman teknologi informasi, kendala penyusunan laporan keuangan.

Pada studi penelitian yang dilakukan Mulyani, Nurhayaty, dan Miharja (2019) disimpulkan bahwa para pelaku UMKM belum melakukan proses Akuntansi secara lengkap karena sulit dan rumit, namun sudah menerapkan pengumpulan bukti transaksi, masih mencampurkan uang pribadi dan usahanya, mengambil keputusan berdasarkan pengalaman karena tanpa Akuntansi mereka bisa berhasil. Kesimpulan penelitian Savitri (2018) menyatakan bahwa pelaku UMKM belum menerapkan pencatatan akuntansi, hanya mencatat pembelian bahan baku dan biaya. Penelitian Misnianningsih (2019) memberikan kesimpulan bahwa adanya keterbatasan waktu dan Sumber Daya Manusia yang membuat pelaku UMKM tidak mencatat transaksi kedalam Laporan Keuangan, ada pelaku UMKM melakukan pencatatan transaksi namun tidak sesuai dengan Standar. Hal ini sebelumnya diteliti oleh Sulistyowati (2017) yang menyatakan bahwa pelaku UMKM belum siap karena tidak memahami Standar Akuntansi Keuangan.

Jawa Timur, khususnya Kabupaten Bojonegoro memiliki UMKM lebih dari 2.000 yang tersebar di berbagai daerah Bojonegoro dan berbagai industri. Pelaku UMKM di Kabupaten Bojonegoro ada yang sudah lama berdiri, dan ada yang masih baru. Mereka berwiraswasta untuk mencari penghasilan dan ada yang untuk menambah penghasilan/ membantu suami mencari uang. Industri yang paling banyak di Bojonegoro adalah berupa jasa dan perdagangan.

Masalah yang dihadapi pelaku UMKM di Kabupaten Bojonegoro dalam mengembangkan usahanya adalah mereka tidak mengetahui kinerja dari usaha bisnisnya maju atau tidak. Informasi yang diperoleh adalah berdasar hasil penjualan saja. Jika dalam sebulan omzet mereka meningkat berarti dianggap kinerjanya bagus, namun jika menurun maka kinerjanya tidak bagus. Tidak jarang dari mereka untuk membeli barang dagang atau persediaan usahanya memakai uang rumah tangga sehingga mengganggu kehidupan rumah 
tangga juga. Namun jika usahanya sedang meningkat penjualannya, hasilnya biasanya digunakan untuk kepentingan pribadi misalnya untuk berlibur atau untuk membeli smartphone, TV dan lain-lainnya.

Latar belakang pendidikan para pelaku UMKM di Kabupaten Bojonegoro rata-rata bukan Sarjana dan yang pernah kuliah bukan dari jurusan Akuntansi. Hal tersebut menimbulkan ketidaktahuan mereka mengenai pencatatan transaksi keuangan berdasarkan standar. Beberapa dari pelaku UMKM ada yang sudah mencatat traksaksi keuangannya, namun masih sebatas transaksi penjualan dan pembelian saja dan banyak dari pelaku UMKM ini masih belum mengetahui Laporan Keuangan yang sesuai dengan Standar Akuntansi Keuangan (SAK).

Dewan Standar Akuntansi Keuangan Ikatan Akuntan Indonesia pada tahun 2009 menerbitkan SAK ETAP (Standar Akuntansi Keuangan Entitas Tanpa Akuntabilitas Publik) untuk dapat digunakan sebagai pedoman oleh entitas kecil dan menengah dalam menyusun Laporan Keuangan. Namun, dalam perkembangannya masih dirasa sulit oleh pelaku UMKM karena keterbatasan sumber daya manusia. Pada akhirnya diterbitkan SAK EMKM (Standar Akuntansi Keuangan Entitas Mikro Kecil dan Menengah) di tahun 2016 yang berlaku efektif 1 Januari 2018. Standar Akuntansi Keuangan EMKM ini lebih sederhana daripada SAK ETAP. Diharapkan dengan lebih sederhana dan mudah maka pelaku UMKM akan dapat menyusun Laporan Keuangan yang sesuai dengan Standar Akuntansi Keuangan.

Kegiatan pengabdian kepada masyarakat di Kabupaten Bojonegoro ini dilaksanakan di bulan April tahun 2018. Kegiatan ini bertujuan untuk memberikan pengetahuan dan pemahaman kepada pelaku UMKM di Kabupaten Bojonegoro mengenai Akuntansi dan manfaat dari penyusunan Laporan Keuangan sesuai dengan Standar Akuntansi Keuangan. Tujuan berikutnya dari kegiatan ini juga untuk mensosialisasikan Standar Akuntansi Keuangan EMKM kepada pelaku UMKM sehingga mereka dapat menyusun Laporan Keuangan sesuai dengan Standar yang telah ditetapkan oleh organisasi profesi Ikatan Akuntan Indonesia.

Adanya kegiatan pengabdian kepada masyarakat ini diharapkan para pelaku UMKM dapat memahami dasar-dasar Akuntansi sehingga dapat menyusun Laporan Keuangan sesuai dengan SAK EMKM. Apabila pelaku UMKM telah mampu menyusun Laporan Keuangan sesuai SAK EMKM maka diharapkan dapat membuat keputusan berdasarkan informasi yang diperoleh dari Laporan Keuangan.

Kegiatan Pengabdian Kepada Masyarakat berupa Bimbingan Teknis kepada Pelaku UMKM di Kabupaten Bojonegoro diharapkan dapat menjawab permasalahan yang selama ini menjadi kendala UMKM. Pelatihan Akuntansi dan penyusunan Laporan Keuangan masih dilakukan secara manual meski sekarang sudah memasuki era industri 4.0. Hal ini dikarenakan pelaku UMKM masih ada yang belum mempunyai data keuangan sebab belum mencatat transaksi keuangannya. Hasil penelitian Achadiyah (2019) menyatakan bahwa implementasi otomatisasi pencatatan akuntansi pada UMKM memiliki keterbatasan sulitnya identifikasi komponen Laporan Keuangan dikarenakan sebelumnya tidak ada pembukuan secara akuntansi dan tidak ada data-data.

\section{METODE PELAKSANAAN}

Metode pelaksanaan yang dilakukan dalam kegiatan ini adalah sosialisasi, pelatihan dan pendampingan. Tahapan dalam kegiatan pengabdian untuk mencapai tujuan adalah yang pertama dilakukan survey pendahuluan. Kami bekerjasama dengan Dinas Koperasi dan UKM Provinsi Jawa Timur. Survey pendahuluan dilakukan oleh Dinkop UKM Provinsi Jawa Timur untuk mengetahui permasalahan yang ada sehingga kegiatan yang diberikan dapat menjadi solusi permasalahan. 
Tahapan selanjutnya adalah melaksanakan bimbingan teknis kepada pelaku UMKM Kabupaten Bojonegoro yang bergerak di bidang jasa dan perdagangan. Peserta diberikan sosialisasi mengenai pemahaman dasar-dasar Akuntansi dan pentingnya Laporan Keuangan. Pelaku UMKM Kabupaten Bojonegoro diperkenalkan untuk mencatat transaksi keuangan dan menyusun Laporan Keuangan sesuai dengan SAK EMKM. Metode yang dipergunakan ini sejalan dengan hasil penelitian yang dilakukan oleh Kusuma, Indra Cahya dan Via Lutfiany (2018) bahwa pemahaman akuntansi merupakan variabel dominan dari implementasi SAK EMKM. Kemudian hasil penelitian dari Badria, Nuril dan Nur Diana (2018) menyatakan bahwa sosialisasi berpengaruh pada penggunaan SAK bersama-sama dengan persepsi.

Tahapan akhir dari bimbingan teknis ini adalah melakukan evaluasi. Tim melakukan evaluasi dengan cara membandingkan pemahaman peserta sebelum dan setelah kegiatan. Evaluasi ini dilakukan dengan memberikan pertanyaan kepada peserta dan memberikan hadiah kepada peserta yang dapat menjawab. Dari evaluasi tersebut dapat diketahui apakah kegiatan yang dilakukan sudah dapat memberikan solusi atas permasalahan.

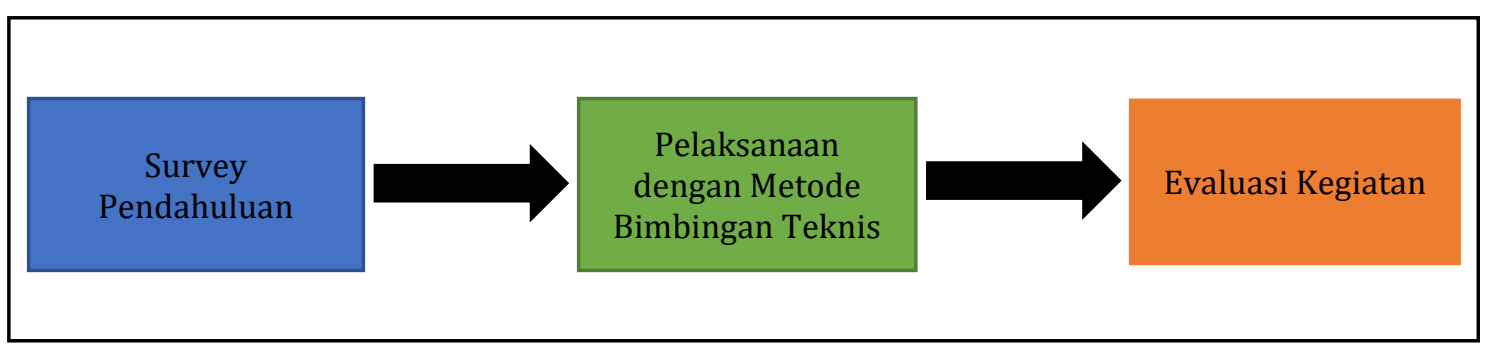

Gambar 1. Metode Pelaksanaan

(Sumber : Penulis)

\section{HASIL dan PEMBAHASAN}

Hasil kegiatan Pengabdian Kepada Masyarakat dengan memberikan Bimbingan Teknis kepada Pelaku UKM di Kabupaten Bojonegoro telah sesuai dengan rencana yang telah disusun bersama tim. Pada tahapan pertama yaitu survey pendahuluan yang dibantu oleh Tim Dinas Koperasi dan UKM Provinsi Jawa Timur dihasilkan bahwa pelaku UKM di Kabupaten Bojonegoro masih ada yang belum mencatat transaksinya. Adapun yang sudah mencatat transaksinya hanya sederhana saja, terbatas penjualan dan pembelian barang dagang maupun persediaan. Kemudian ada pelaku UKM yang hanya menyusun Laporan Laba Rugi saja dan rata-rata dari pelaku UKM Kabupaten Bojonegoro masih mencampur antara aset usaha dengan pribadi.

Bimbingan Teknis yang dilakukan berlangsung selama 2 hari. Kegiatan dilangsungkan di Hotel Dewarna Bojonegoro pada tanggal 10-11 April 2018. Bimbingan teknis ini diikuti oleh para pelaku UKM Kabupaten Bojonegoro dari industri jasa dan perdagangan (Gambar 2). Acara dibuka oleh tim dari Dinas Koperasi dan UKM Provinsi Jawa Timur sekaligus membacakan curriculum vitae dari tim pengabdian kepada masyarakat kepada para peserta agar yakin bahwa mereka dilatih oleh Akuntan yang mempunyai kompetensi di bidangnya (Gambar 3). Peserta diberikan pemahaman Akuntansi dan pentingnya menyusun Laporan Keuangan terlebih dahulu. Kami memberikan motivasi juga kepada pelaku UKM untuk menyusun Laporan Keuangan dengan harapan pemilik usaha mempunyai kesadaran sendiri dalam mencatat transaksi keuangannya (Gambar 4). 
Sebelum kegiatan dimulai, peserta sudah diberikan materi yang akan disampaikan supaya peserta dapat membacanya terlebih dahulu. Berikut adalah kegiatan pengabdian bersama peserta.

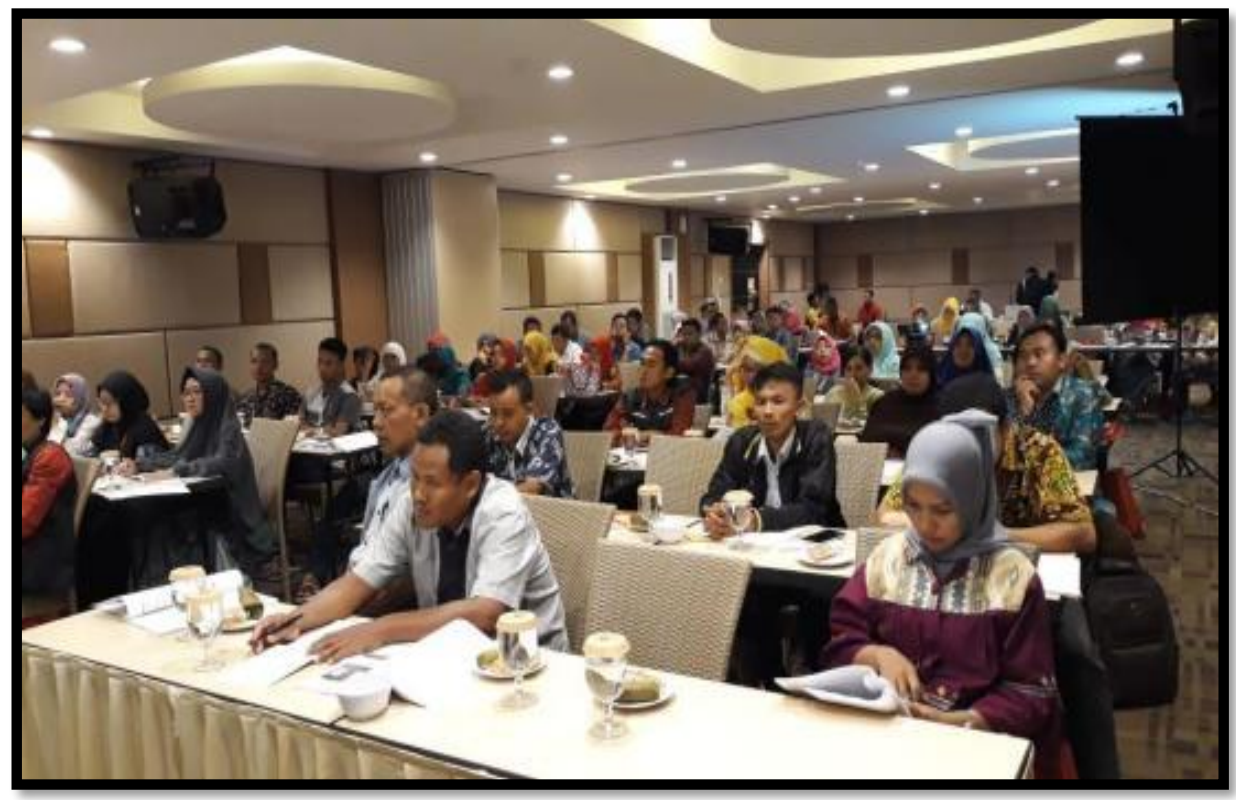

Gambar 2. Peserta Pelatihan Bimtek

(Sumber : Dokumen Pribadi Penulis)

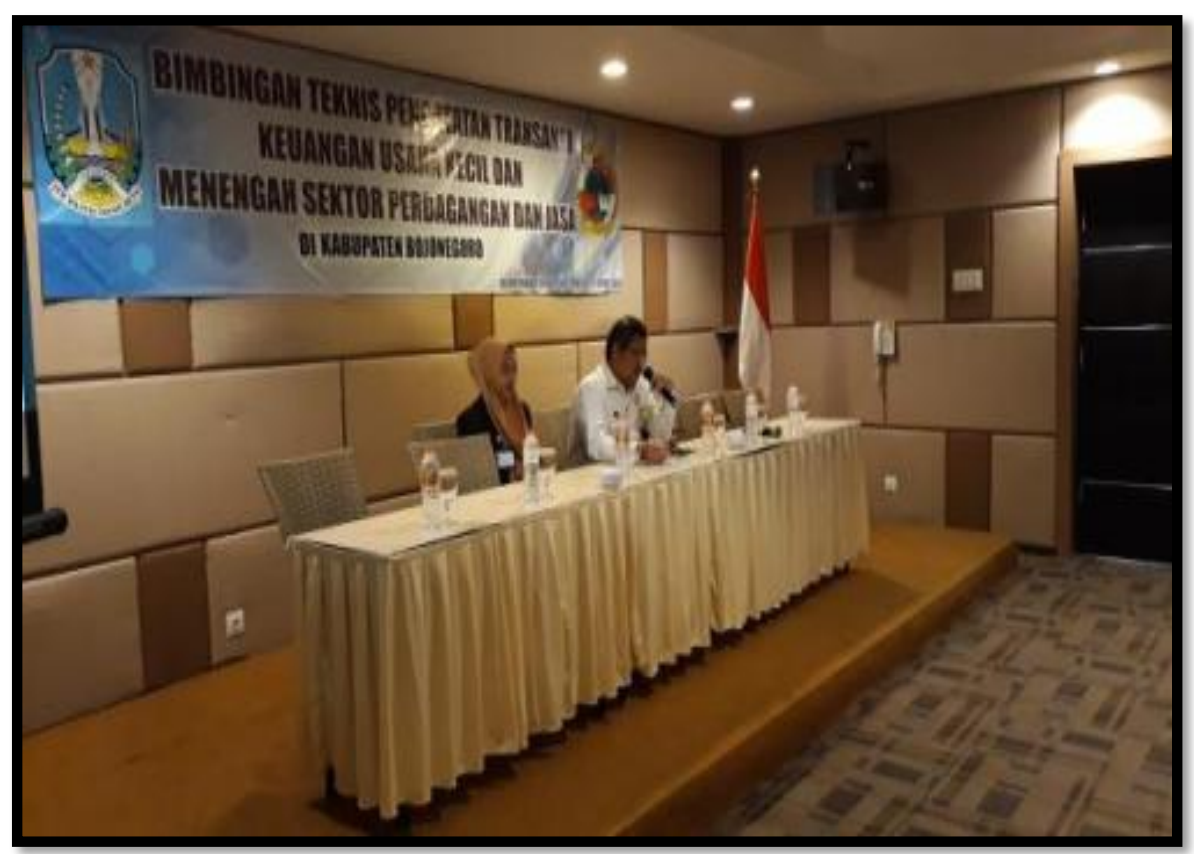

Gambar 3. Pembukaan dan Perkenalan dari Dinkop UKM Provinsi Jawa Timur (Sumber : Dokumen Pribadi Penulis) 

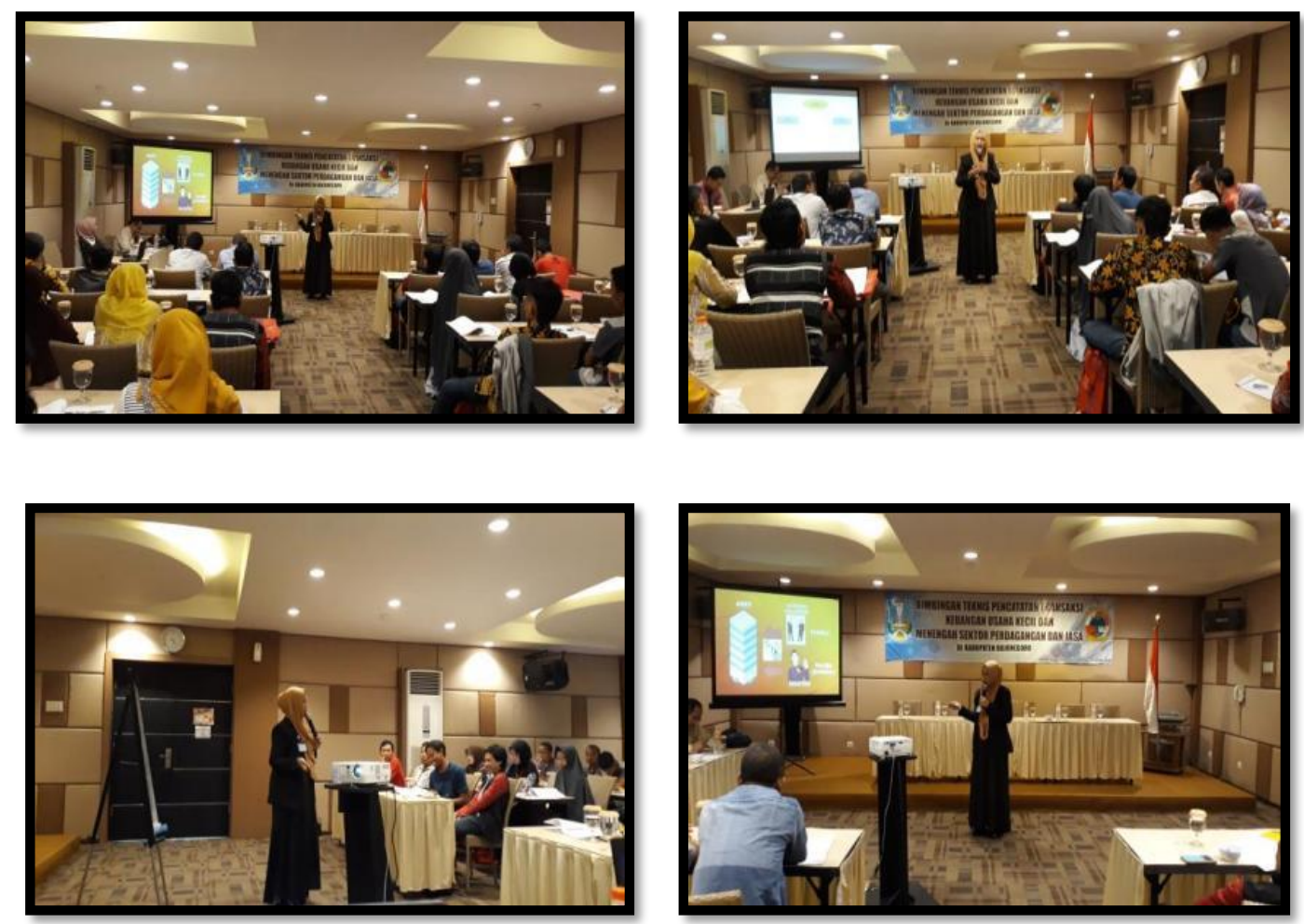

Gambar 4. Penjelasan Dasar-Dasar Akuntansi dan Motivasi Kepada Peserta (Sumber : Dokumen Pribadi Penulis)

Kemudian selanjutnya diberikan pengenalan mengenai penyusunan Laporan Keuangan berdasarkan SAK EMKM. Peserta diberikan contoh terlebih dahulu dimulai pencatatan transaksi kedalam jurnal sampai menjadi Laporan Keuangan yang sesuai dengan SAK EMKM. Setelah itu peserta diberikan kasus untuk dapat dikerjakan dan dapat mengajukan pertanyaan jika belum memahami (Gambar 5). Untuk mengetahui kemampuan peserta setelah diberikan pelatihan, maka peserta diminta untuk menjawab kasus yang diberikan. Bagi peserta yang dapat menjawab kasus tersebut akan diberikan hadiah berupa buku SAK EMKM (Gambar 6).

Pada sesi tanya jawab, ada peserta yang bertanya kenapa bimbingan teknis ini tidak langsung memanfaatkan teknologi yaitu dengan menggunakan komputer. Alasan kami memberikan bimbingan teknis ini dengan cara manual terlebih dahulu karena pengetahuan mengenai teknologi para peserta beragam, jadi tidak semua familiar dengan komputer. Kemudian alasan berikutnya adalah karena kami menginginkan agar peserta memahami secara sederhana dulu pencatatan transaksi keuangan sesuai dengan SAK EMKM. Harapan kami dapat menindaklanjuti bimbingan teknis ini kedepannya menggunakan teknologi komputer atau smartphone agar peserta dapat terbantu pekerjaannya dalam mencatat transaksi keuangannya. 

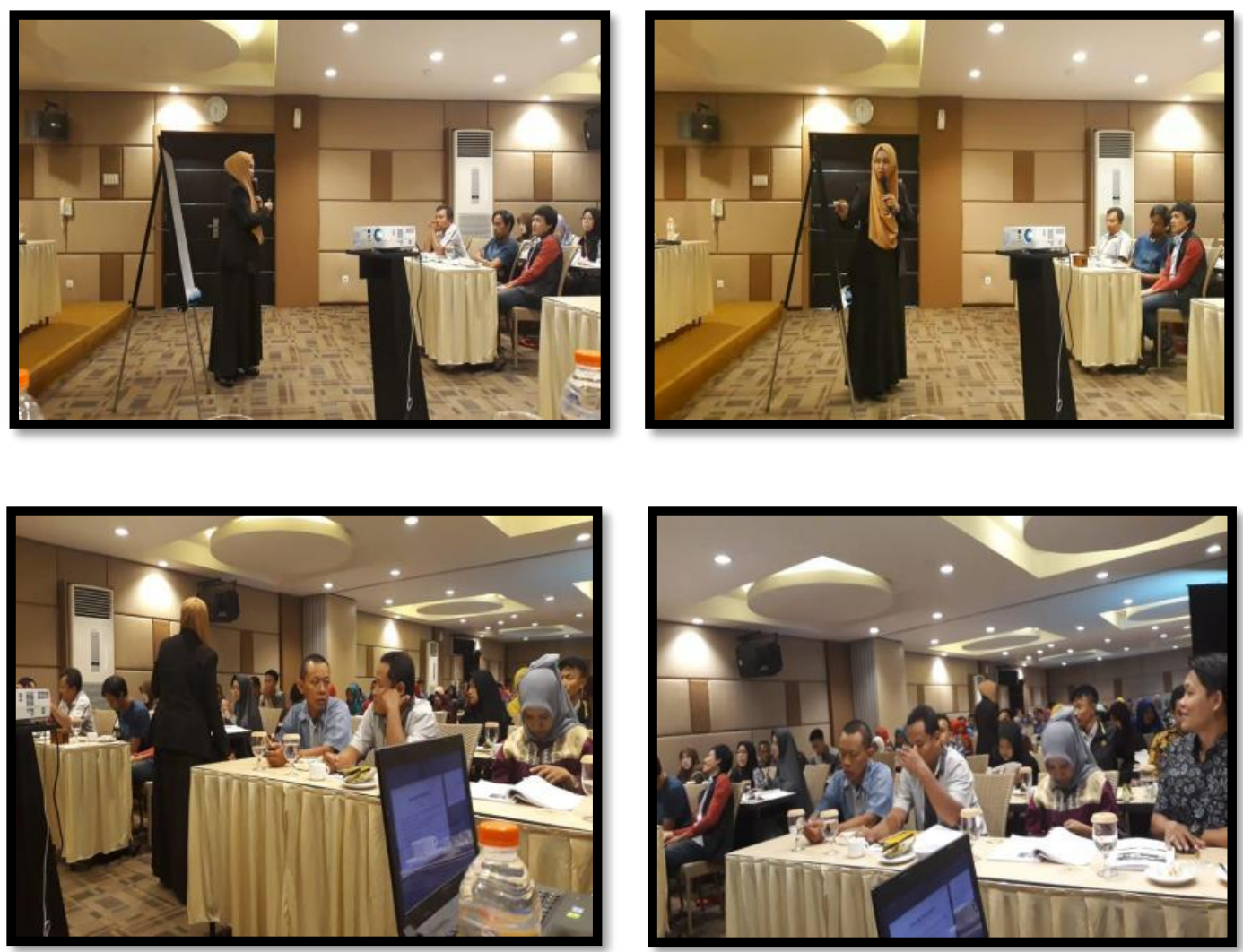

Gambar 5. Penjelasan Penyusunan Laporan Keuangan sesuai SAK EMKM (Sumber : Dokumen Pribadi Penulis)

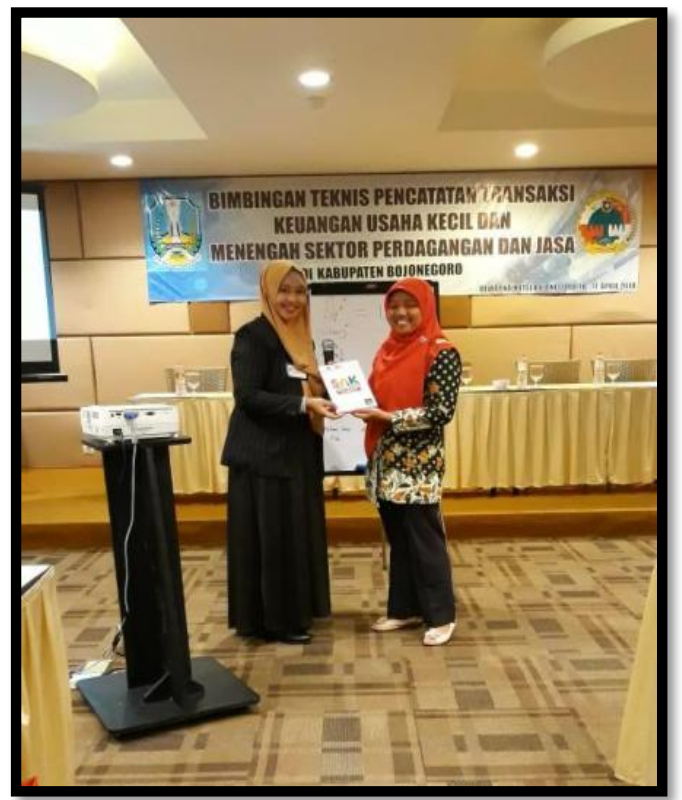

Gambar 6. Peserta Mendapat Hadiah SAK EMKM (Sumber : Dokumen Pribadi Penulis) 


\section{KESIMPULAN}

Bimbingan Teknis pencatatan transaksi keuangan sesuai SAK EMKM merupakan salah satu solusi yang dapat diberikan agar pelaku UKM dapat meningkatkan daya saing di era industri 4.0. Pencatatan transaksi yang dilakukan dapat digunakan sebagai sumber informasi bagi pelaku UKM untuk lebih mengefisiensikan biayanya, mengetahui perkembangan usahanya dan dapat membuat strategi bisnis kedepannya.

Pelaksanaan kegiatan ini berjalan dengan lancar, peserta mengikuti acara sampai selesai. Peserta juga antusias dalam bertanya dan menjawab kasus yang diberikan dimana di akhir acara terdapat peserta yang mendapat hadiah buku SAK EMKM karena berhasil menjawab. Setelah diberikan Bimbingan Teknis, pengetahuan peserta sudah bertambah menjadi paham mengenai pemisahan kekayaan pribadi dengan usaha, pencatatan transaksi yang berguna bagi mereka, dan manfaat dalam penyusunan laporan keuangan sesuai SAK EMKM. Pelaku UKM juga pada akhirnya mengetahui bahwa Laporan Keuangan yang disusun sangat sederhana daripada yang dibayangkan sebelumnya. Laporan Keuangan yang harus disusun oleh pelaku UKM hanya berupa Laporan Posisi Keuangan, Laporan Laba Rugi dan Catatan atas Laporan Keuangan.

\section{UCAPAN TERIMAKASIH}

Atas Berkah dan Rahmat dari Allah Subhanahu Wa Ta'ala serta salam dan sholawat kami sampaikan kepada Nabi Muhammad Shalallahu Alaihi Wassalam sehingga kegiatan Bimbingan Teknis ini berjalan dengan lancar. Tidak lupa kami ucapkan terimakasih kepada pihak-pihak yang bekerjasama dan mendukung kegiatan ini. Terimakasih kepada Dinas Koperasi dan UKM Provinsi Jawa Timur atas kerjasamanya dalam mewujudkan kegiatan Bimbingan Teknis kepada UKM Kabupaten Bojonegoro, kepada Ketua Sekolah Tinggi Ilmu Ekonomi Indonesia (STIESIA) Surabaya yang menfasilitasi pelaksanaan kegiatan tersebut, kepada Kepala Lembaga Penelitian dan Pengabdian Kepada Masyarakat (LP2M) STIESIA Surabaya yang telah membimbing untuk kegiatan Pengabdian Kepada Masyarakat, serta kepada peserta yang bersedia meluangkan waktunya untuk hadir dan antusias untuk mengikuti acara tersebut dari awal hingga akhir.

\section{DAFTAR PUSTAKA}

Achadiyah, B. N. (2019). Otomatisasi Pencatatan Akuntansi Pada UMKM. Jurnal Akuntansi Multiparadigma, https://doi.org/10.18202/jamal.2019.04.10011

$10(1)$.

Andarsari, P. R., \& Dura, J. (2018). IMPLEMENTASI PENCATATAN KEUANGAN PADA USAHA KECIL DAN MENENGAH (Studi pada Sentra Industri Kripik Tempe Sanan di Kota Malang). Jurnal JIBEKA, 12, 59-64. https://media.neliti.com/media/publications/262609-implementasipencatatan-keuangan-pada-us-334acce7.PDF

Badria, N., \& Diana, N. (2015). persepsi pelaku UMKM dan sosialisasi SAK EMKM terhadap diberlakukannya laporan keuangan yang berbasis SAK EMKM. $D k$, 53(9), 1689-1699.

Diskopukm.jatimprov.go.id. Bank Data - Dinas Koperasi dan UKM Jatim. Diakses pada 3 November 2020, dari https://data.diskopukm.jatimprov.go.id/

Kusuma, I. C., \& Lutfiany, V. (2019). Persepsi UMKM Dalam Memahami SAK EMKM. Jurnal Akunida, 4(2), 1. https://doi.org/10.30997/jakd.v4i2.1550

Ikatan Akuntan Indonesia. (2016). Standar Akuntansi Keuangan Entitas Mikro, Kecil dan Menengah. Jakarta.

Misnianningsih, Lusy Nur. (2019). Penerapan Laporan Keuangan Usaha Mikro Kecil 
dan Menengah (UMKM) di Kecamatan Pahandut Kota Palangkaraya. Skripsi. Palangkaraya: Institut Agama Islam Negeri Palangkaraya Fakultas Ekonomi dan Bisnis Islam.

Mulyani, A. S., Nurhayaty, E., \& Miharja, K. (2019). Penerapan Pencatatan dan Laporan Akuntansi Pada Usaha Mikro Kecil Dan Menengah (UMKM). Jurnal Abdimas BSI: Jurnal Pengabdian Kepada Masyarakat, 2(2), 219-226. https://doi.org/10.31294/jabdimas.v2i2.5818

Puspitaningtyas, Z. (2017). Pembudayaan Pengelolaan Keuangan Berbsis Akuntansi bagi Pelaku UKM. Jurnal Akuntansi, XXI(03), 361-372.

Savitri, R. V. (2018). PENCATATAN AKUNTANSI PADA USAHA MIKRO KECIL DAN MENENGAH ( STUDI PADA UMKM MR . PELANGI SEMARANG) Keywords: accounting records, UMKM Kata Kunci: Pencatatan Akuntansi, UMKM Corresponding author: 5(2), 117-125. https://ejournal.unsrat.ac.id/index.php/imbi/article/view/20808/20499

Sulistyowati, Y. (2017). Pencatatan Pelaporan Keuangan UMKM (Study Kasus Di Kota Malang). Referensi : Jurnal Ilmu Manajemen Dan Akuntansi, 5(2), 49. https://doi.org/10.33366/ref.v5i2.831

Syahrenny, Nenny. (2020). Pelatihan Penyusunan Laporan Keuangan UMKM Sesuai SAK EMKM. Prosiding Seminar Nasional Penelitian dan Pengabdian Kepada Masyarakat.

13-17. http://snp2m.unim.ac.id/index.php/snp2m/article/view/404/249 